TITLE:

\title{
Species Composition, Distribution and Abundance of Hydromedusae in the Exclusive Economic Zone of the East Coast of India
}

\section{$\operatorname{AUTHOR}(\mathrm{S}):$}

Santhakumari, V.

\section{CITATION:}

Santhakumari, V.. Species Composition, Distribution and Abundance of Hydromedusae in the Exclusive Economic Zone of the East Coast of India. PUBLICATIONS OF THE SETO MARINE BIOLOGICAL LABORATORY 1997, 38(1-2): 53-61

ISSUE DATE:

1997-12-25

URL:

http://hdl.handle.net/2433/176271

RIGHT: 


\title{
Species Composition, Distribution and Abundance of Hydromedusae in the Exclusive Economic Zone of the East Coast of India
}

\author{
V. Santhakumari* \\ National Institute of Oceanography, Regional Centre, Cochin, 682018, Kerala, India
}

\begin{abstract}
Based on zooplankton collections made by Fisheries Ocean Research Vessel Sagar Sampada Central Marine Fisheries Research Institute, India, during the period 1986-1990, 356 samples from 18 cruises from Sri Lanka to Calcutta coast were analysed. The hydromedusae were encountered in 273 samples and more than 62 species were found. Liriope tetraphylla dominated in the percentage of occurrence and population density. Aglaura hemistoma, Solmundella bitentaculata, Rhopalonema velatum, Cytaeis tetrastyla, Bougainvillia fulva and Phialidium hemisphaericum were the commonly occurring species. The maximum species diversity was noticed away from the nearshore stations, while maximum population density was from nearshore stations.
\end{abstract}

Key words: hydromedusae, species composition, distribution, abundance, east coast of India

\section{Introduction}

Distribution of hydromedusae in the Indian Ocean including the Bay of Bengal was reported by Navas (1971), Vannucci and Navas (1973a, b, c) and Santhakumari (1977a) based on the samples in the International Indian Ocean Expedition (1962-1965). But in this expedition coastal areas were not thoroughly sampled. A comprehensive study from the coast of India, especially in its exclusive economic zone (EEZ), has not been undertaken. The available information on the distribution of hydromedusae is confined to areas off the southwest coast of India (Nair, 1954; Vannucci and Santhakumari, 1969; Santhakumari, 1977a, b, 1991). The only a report about the destribution of hydromedusae from the east coast of India is by Ganapati and Nagabhushanam (1958) who recorded the seasonal distribution of hydromedusae from Visakhapatnam. The present paper deals with the distribution of hydromedusae based on the material collected by FORV Sagar Sampada from the EEZ of the east coast of India.

\section{Materials and Methods}

Samples were collected in 18 cruises on board FORV Sagar Sampada from the EEZ of the east coast of India, from Sri Lanka to Calcutta, during the period 1986-1990. By an oblique haul from $150 \mathrm{~m}$ depth to surface using Bongo net (mouth diameter $60 \mathrm{~cm}$; mesh aperture $0.33 \mathrm{~mm}$ ) equipped with a calibrated flow meter, 356 zooplankton samples were taken and preserved in $5 \%$ formalin sea water solution, and the hydromedusae were separated and analysed. The sampling details were presented in the cruise reports (Central Marine Fisheries Research Institute, 1986). Hydromedusae counts were transformed to numbers per unit volume using flow meter data.

* We are very much regretted to inform that Dr. V. Santhakumari passed away unexpectedly on November 26, 1997 due to heart failure. 


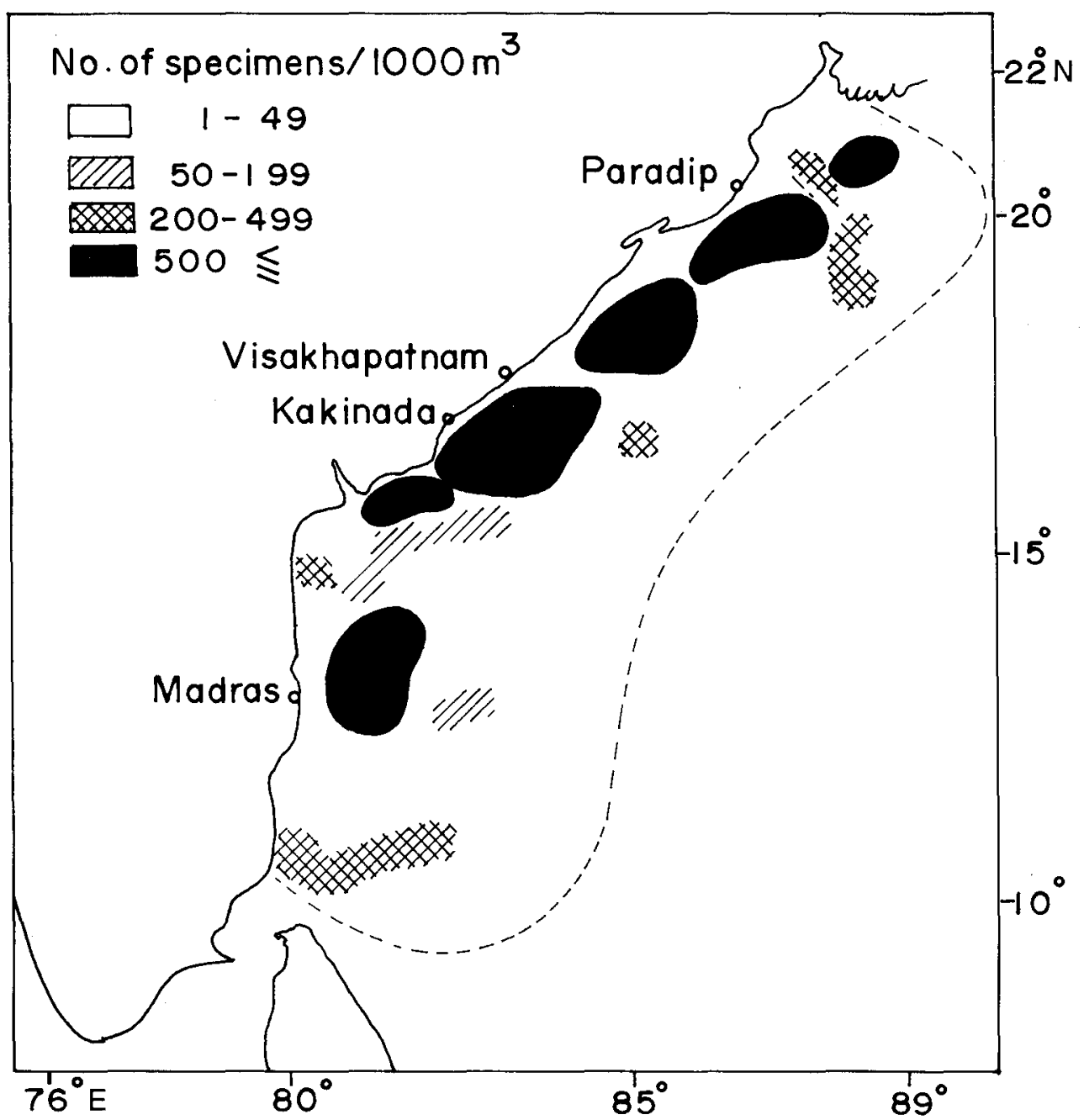

Fig. 1. Abundance of hydromedusae from EEZ of east coast of India during 1986-1990.

\section{Results and Discussion}

Species composition

More than 62 species of 37 genera were found as given below according to the order. In this collection no new members of the hydromedusae in the Indian Ocean were recorded.

\section{Anthomedusae}

Sarsia mirabilis Agassiz

Hybocodon unicus Browne, H. forbesi Mayer

Ectopleura dumortieri Van Beneden

Euphysora bigelowi Maas, E. normani Browne

Zanclea dubia Kramp 


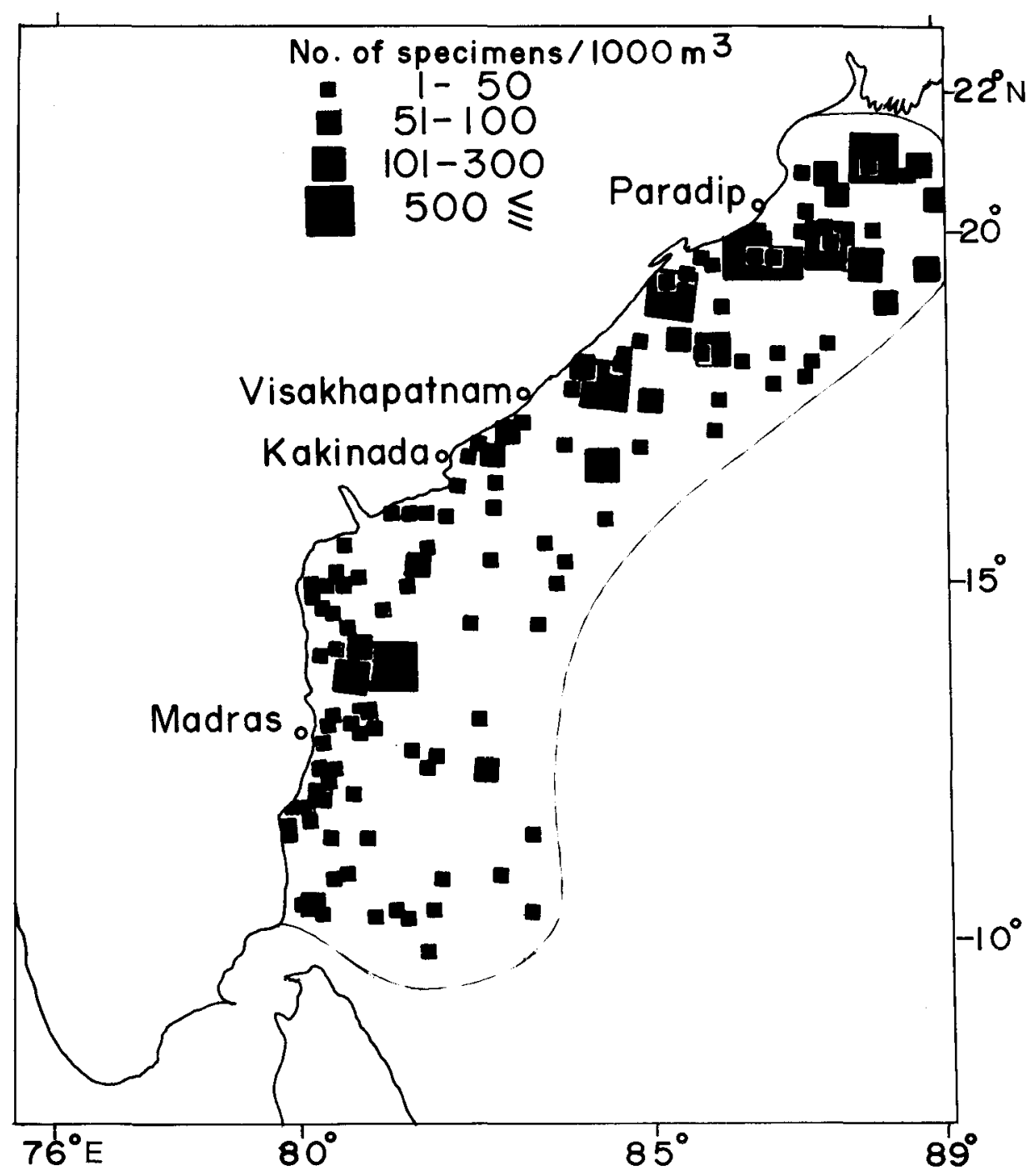

Fig. 2. Distribution and abundance of Liriope tetraphylla.

Cnidocodon leopoldi Bouillon

Cytaeis tetrastyla Eschscholtz, C. vulgaris Agassiz and Mayer

Lizzia gracilis Mayer

Podocoryne apicata Kramp

Bougainvillia bitentaculata Uchida, B. fulva Agassiz and Mayer, B. platygaster Haeckel, B. ramosa Van Beneden

Kollikerina octonemalis Maas

Merga tergestina Neppi and Stiasny

Amphinema rugosum Mayer

Octotiara russelli Kramp 


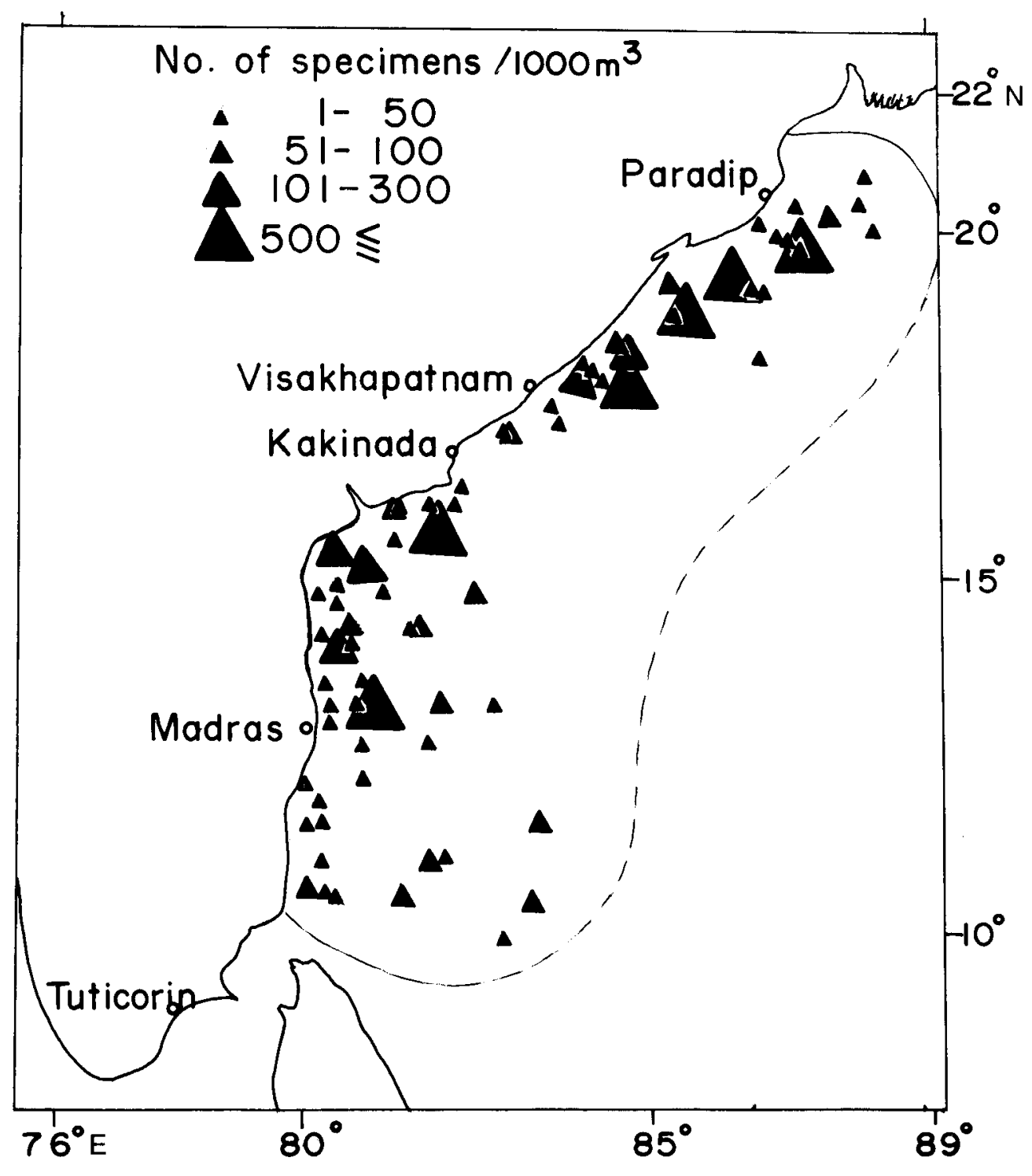

Fig. 3. Distribution and abundance of Aglaura hemistoma.

Leuckartiara octona Fleming

\section{Leptomedusae}

Obelia spp.

Phialidium hemisphaericum (L.), P. simplex Browne, P. brunescens Bigelow, P. globosum Mayer Eucheilota menoni Kramp, E. tropica Kramp

Phialucium carolinae Mayer, $P$. multitentaculatum Menon

Octophialucium indicum Kramp, O. bigelowei Kramp

Eirene elliceana Agassiz and Mayer, E. ceylonensis Browne, E. hexanemalis Goette Helgicirrha malayensis Stiasny 


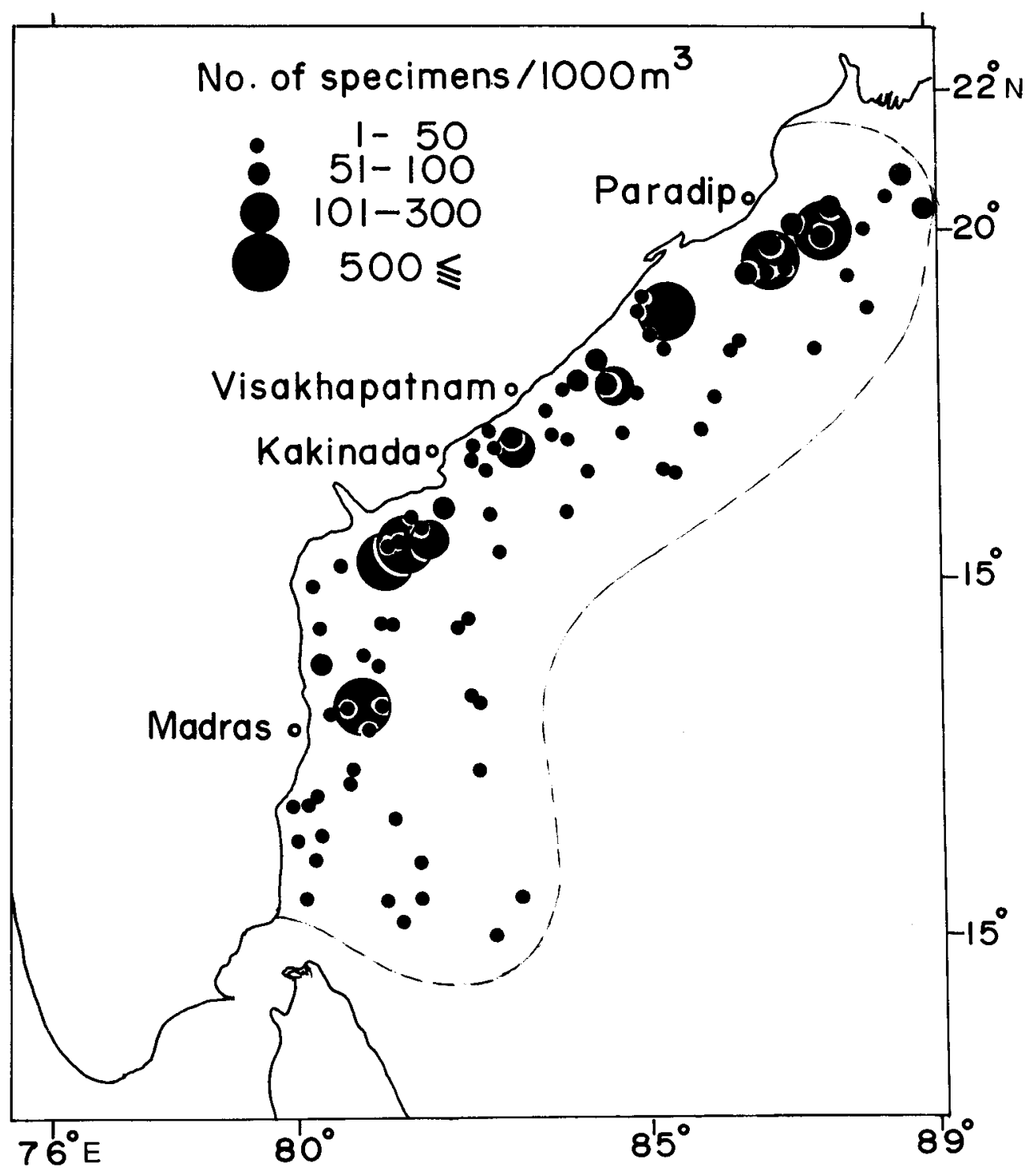

Fig. 4. Distribution and abundance of Solmundella bitentaculata.

Eutima mira McCrady, E. curva Browne

Aequorea aequorea, Forskål, A. conica Browne, A. globosa Eschscholtz, A. pensilis Eschscholtz, A. parva Browne

\section{Limnomedusae}

Proboscidactyla ornata McCrady

\section{Trachymedusae}

Rhopalonema velatum Gegenbaur, R. funerarium Vanhöffen,

Pantachagon scotti Browne, P. haeckeli Maas 


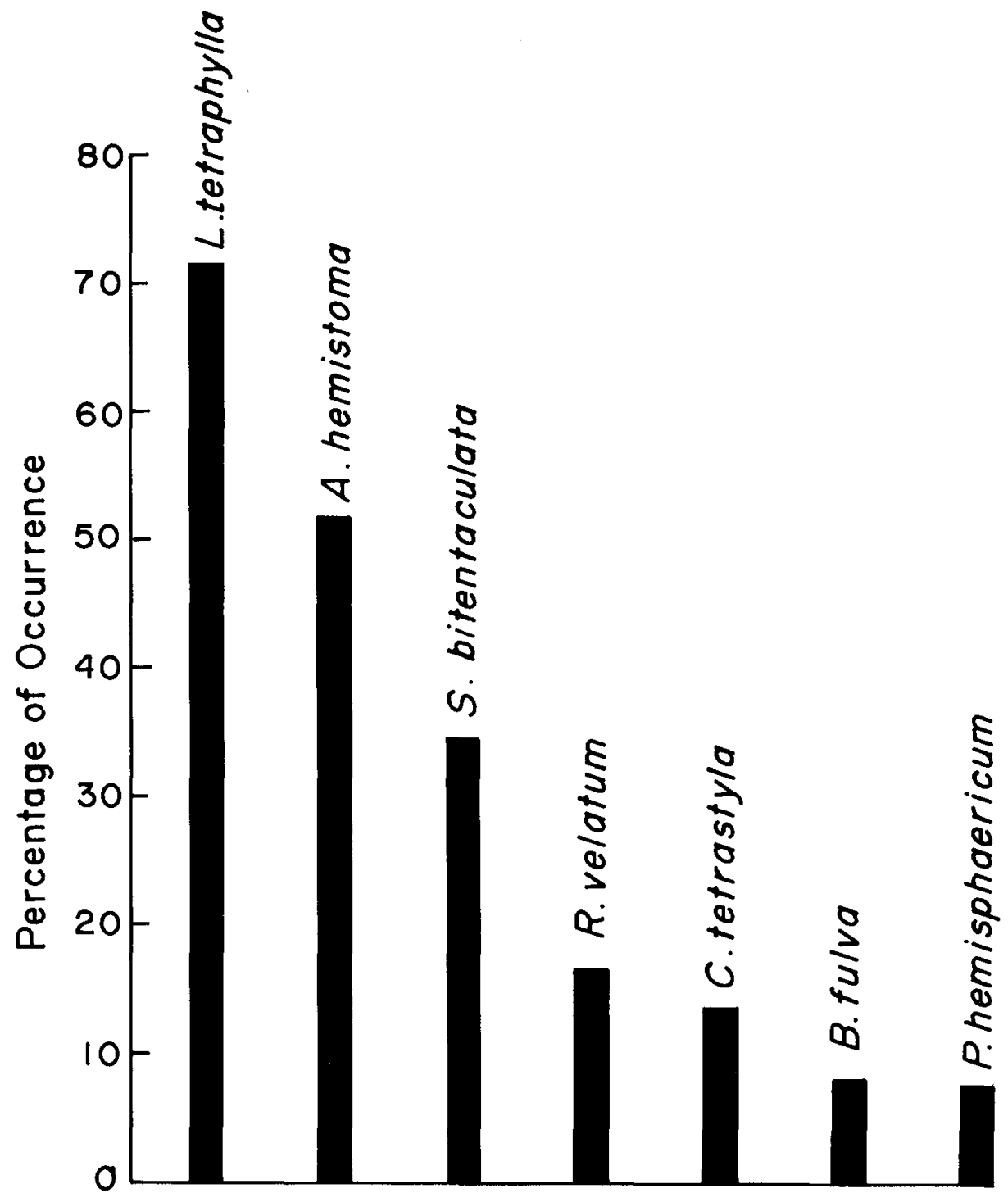

Hydromedusae species

Fig. 5. Percentage of occurrence of common species.

Amphogona apicata Kramp

Crossota alba Bigelow, C. brunnea Vanhöffen

Aglaura hemistoma Péron and Lesueur, A. elata Haeckel

Geryonia proboscidalis Forskål

Liriope tetraphylla Chamisso and Eysenhardt 


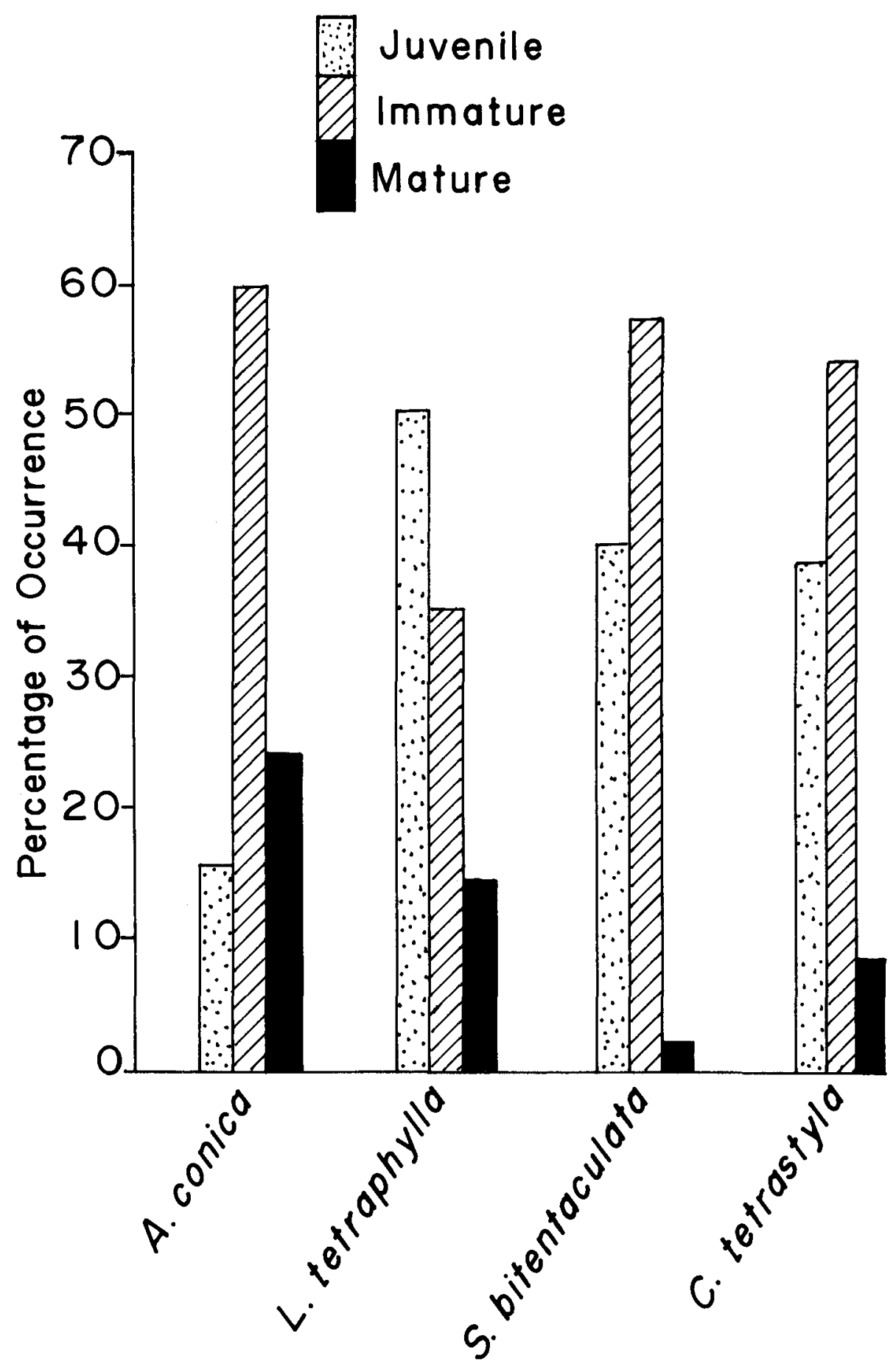

Fig. 6. Percentage composition of the different maturity stages of common species. 


\section{Narcomedusae}

Aegina citrea Eschscholtz

Solmundella bitentaculata Quoy and Gaimard

Pegantha clara Bigelow

Solmaris lenticulata Haeckel

Cunina octonaria McCrady, C. tenella Bigelow, C. duplicata Maas

Abundance and distribution

Hydromedusae were obtained from 273 out of the 356 samples $(76.7 \%$ of the samples). Dense population of hydromedusae, more than 500 inds. $/ 1000 \mathrm{~m}^{3}$, was recorded from off Madras to off Paradip and the highest density, 5941 inds. $/ 1000 \mathrm{~m}^{3}$, was recorded off Paradip. Low population densities were encountered in many stations, covering larger areas (Fig. 1).

Liriope tetraphylla, one of the holoplanktonic species, occupied the most dominant position with $71.1 \%$ occurrence (Figs. 2, 5) and its maximum population density was 3552 inds. $/ 1000 \mathrm{~m}^{3}$ off Paradip. This species has a very wide distribution in the study area. The second dominant species in the percentage of occurrence $(51.8 \%)$ was Aglaura hemistoma, one of the holoplanktonic species (Figs. 3, 5). These two species were often seen in the same collections whereas they excluded each other when one of them occurred in swarms. A. hemistoma was reported as the most dominant species of the EEZ of the west coast of India (Santhakumari, 1993), whereas L. tetraphylla was the most dominant species in the east coast of India as is recorded in the present study. Vannucci and Navas (1973a) already recorded a similar trend of dominancy in the distribution of these two species, $A$. hemistoma in the Bay of Bengal and L. tetraphylla in the Arabian Sea, respectively.

Solmundella bitentaculata occupied the third position in the percentage of occurrence $(34.5 \%)$ (Figs, 4, 5) and Rhopalonema velatum occupied 4th position in percentage composition. Other commonly occurring species like Cytaeis tetrastyla, Bougainvillia fulva and Phialidium hemisphaericum occurred in low numbers (Fig. 5) and were restricted to near shores.

Aequorea conica was also observed frequently in fairly high population density in the coastal areas, but in very low (less than $10 \%$ ) percentage of occurrence. Santhakumari (1991) had recorded dense swarms (highest record of 181 inds. $/ \mathrm{m}^{3}$ ) of this species from the southwest coast of India.

Phialucium indicum, P. brunescens, Eutima mira, Geryonia proboscidalis, Aequorea aequorea and Euphysora bigelowi appeared only occasionally from little away from coastal stations.

Deep water species Crossota alba, Aegina citrea, Pegantha clara and Aglantha elata were not abundant in population density and not frequently found in the collections. This was due to the shallow collection depth $(0-150 \mathrm{~m})$.

The remaining species occurred only once or twice in the present samples.

Juveniles and immature stages were dominant in common species, especially in Solmundella bitentaculata (Fig. 6).

\section{Acknowledgements}

The author expresses her gratitude to the Director, Central Marine Fisheries Research Institute, Cochin for providing the Sagar Sampada material for the study. She is grateful to Dr. E. Desa, the Director, National Institute of Oceanography, Goa and Dr. V. N. Sankaranarayanan, Scientist-in-charge, National Institute of Oceanography, Cochin for facilities and encouragement. 


\section{SPECIES COMPOSITION, DISTRIBUTION AND ABUNDANGE OF HYDROMEDUSAE IN INDIA}

\section{References}

Central Marine Fisheries Research Instsitute, 1986. Cruise report of FORV Sagar Sampada. Govt. India, DOD, New Delhi, 11-20.

Devassy, V.P., Bhattathiri, P.M.A. \& Radhakrishna, K. 1983. Primary production in the Bay of Bengal during August 1977. Mahasagar. Bull. Nat. Inst. Oceanogr., 16: 443-447.

Ganapati, P.N. \& Nagabhushanam, R. 1958. Seasonal distribution of the hydromedusae off the Visakhapatnam coast. Mem. Oceanogr. Andhra Univ. Ser., 62: 91-99.

Nair, K.K. 1954. Medusae of the Trivandrum coast. Part II. Seasonal distribution. Bull. Res. Inst. Univ. Tranvancore, 3: 32-68.

Navas, D. 1971. New records of hydromedusae from the Indian Ocean. Controes Inst. Oceanogr. Univ. São Paulo, Ser: Ocean Biol., 22: 1-33.

Santhakumari, V. 1977a. Distribution of hydromedusae from Indian Ocean. Proc. Symp. Warm Water Zool. Spl. Publ. UNESCO/NIO: 69-74.

Santhakumari, V. 1977 b. Distribution of hydromedusae along the south west coast of India. Mahasagar Bull. nat. Inst. Oceanogr., 10(1/2): 83-86.

Santhakumari, V. 1991. Ecology, distribution and diel variation of medusae from west coast of India. Proc. 3rd Kerala Sci. Congr, 35-36.

Santhakumari, V. 1993. A study of medusae from Andaman and Nicobar waters. J. Zool. Soc. Kerala, 3: 37-43.

Vannucci, M. \& Navas, D. 1973a. On the ecology of Indian Ocean hydromedusae, IOBC Hand Book, 5: 1-54.

Vannucci, M. \& Navas, D. 1973b. Pattern of distribution of Arabian Sea hydromedusae. Spl. Publ. Mar. Biol. Ass. India, 110-121.

Vannucci, M. \& Navas, D. 1973c. Distribution of hydromedusae in the Indian Ocean. Ed. Berut Zeitzschel. Springer-Verlag. Berlin, Heidelberg, New York. pp. 272-281.

Vannucci, M. \& Santhakumari, V. 1969. New records of hydromedusae from the shelf areas off the Kerala coast. J. Mar. biol. Ass. India, 11: 40-43. 